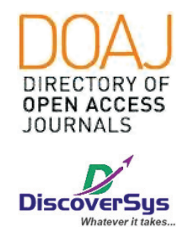

Published by DiscoverSys

\section{Hubungan konsumsi snack, menyikat gigi dan kunjungan dokter gigi terhadap karies pada siswa kelas VII SMP Santo Yoseph Denpasar}

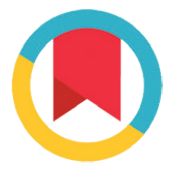

CrossMark
Patricia Eviana Cahyadi, ${ }^{*}$ Steffano Aditya Handoko, ${ }^{2}$ Ni Wayan Arya Utami ${ }^{3}$

\section{ABSTRACT}

Introduction: Dental caries is the most prevalent oral disease in Indonesia that could occur in all age groups. According to the WHO, about 60 - 90\% school children worldwide have dental caries. The aims of this study were to analyze the correlation between snacking (consumption of snacks or sweetened drink), tooth brushing habit and dental visit with caries incidence.

Method: Study design using a cross-sectional analytical study, sampled from one hundred and two seventh grade Santo Yoseph junior high school students. Samples were chosen using purposive random sampling. The data was analyzed using descriptive method and risk estimate with chi-square test.
Result: The prevalence of caries observed in the samples was 52.0\%. The results was statistically significant for correlation between tooth brushing habit and caries incidence $(p=<0.001 ; 0 R=7.44$; Cl $95 \%=2.71-20.42)$. Consumption of snacks or sweetened drink $(p=0.25 ; O R=1.58 ; C l 95 \%=0.71-3.50)$ and dental visit $(p=0.903$; $\mathrm{OR}=1.502 ;(\mathrm{I} 95 \%=0.46-2.37)$ were not statistically significant with caries incidence.

Conclusion: Tooth brushing habit was concluded as the most significant factor in dental caries incidence. It is recommended for school to educate the student about how to brushing teeth properly in collaboration with the primary health care centers.
Keywords: Caries, snacks, tooth brushing, dental visit

Cite This Article: Cahyadi, P.E., Handoko, S.A., Utami, N.W.A. 2018. Hubungan konsumsi snack, menyikat gigi dan kunjungan dokter gigi terhadap karies pada siswa kelas VII SMP Santo Yoseph Denpasar. Intisari Sains Medis 9(3): 35-40. D0I: 10.1556/ism.v9i3.264

\section{ABSTRAK}

'Program Studi Pendidikan Dokter Gigi, Fakultas Kedokteran, Universitas Udayana Kedokteran Gigi, Universitas Udayana

${ }^{3}$ Pengajar Program Studi IImu Kesehatan Masyarakat, Universitas Udayana

\section{*Corresponding:}

Patricia Eviana Cahyadi, Program Studi Pendidikan Dokter Gigi, Fakultas Kedokteran, Universitas Udayana

nanaphen11@gmail.com Disetujui: 2018-07-28 Diterbitkan: 2018-12-1
2Pengajar Program Studi

Diterima: 2018-05-08
Latar Belakang: Karies merupakan penyakit gigi dan mulut yang paling banyak dialami oleh penduduk di Indonesia dan dapat terjadi pada semua golongan usia. Menurut WHO, sekitar 60-90\% anak - anak sekolah di dunia mengalami karies. Tujuan penelitian ini adalah menganalisis hubungan antara konsumsi snack (konsumsi makanan ringan atau minuman manis), menyikat gigi dan kunjungan ke dokter gigi terhadap kejadian karies.

Metode: Penelitian ini merupakan penelitian analitik potong lintang dengan sampel sebanyak 102 siswa kelas VII SMP Santo Yoseph Denpasar. Sampel dipilih menggunakan sistem purposive random sampling. Data dianalisis secara univariat dan bivariat dengan chi-square.

Hasil: Sebanyak 52,0\% sampel dalam penelitian ini mengalami karies. Hasil uji bivariat menunjukkan hubungan yang bermakna secara statistik antara perilaku menyikat gigi terhadap kejadian karies ( $p=<0,001,0 R=7,442$ dan IK 95\% $=2,711-20,429$ ). Terdapat hubungan yang tidak bermakna secara statistik antara perilaku konsumsi makanan atau minuman manis $(p=0,256$; $\mathrm{OR}=1,582$; IK $95 \%=0,716-3,501$ ) dan kunjungan ke dokter gigi ( $p=0,903 ; 0 R=1,502 ;$ IK $95 \%=466-2,372$ ) terhadap kejadian karies. Simpulan: Dapat disimpulkan bahwa faktor yang paling mempengaruhi kejadian karies dalam penelitian ini adalah perilaku menyikat gigi. Disarankan kepada pihak sekolah bekerjasama dengan puskesmas untuk melakukan penyuluhan cara menyikat gigi yang baik dan benar secara berkala.
Kata kunci: Karies, snack, menyikat gigi, kunjungan dokter gigi.

Cite Pasal Ini: Cahyadi, P.E., Handoko, S.A., Utami, N.W.A. 2018. Hubungan konsumsi snack, menyikat gigi dan kunjungan dokter gigi terhadap karies pada siswa kelas VII SMP Santo Yoseph Denpasar. Intisari Sains Medis 9(3): 35-40. D0I: 10.1556/ism.v9i3.264 


\section{PENDAHULUAN}

Kesehatan gigi dan mulut merupakan bagian dari kesehatan tubuh yang ikut berperan dalam menentukan status kesehatan seseorang. Masalah kesehatan gigi yang paling sering ditemukan pada masyarakat ialah karies atau yang lebih dikenal dengan gigi berlubang. Karies dapat terjadi pada semua golongan usia, mulai dari anak - anak hingga lansia. Berdasarkan data World Health Organization sekitar 60 - 90\% anak-anak usia sekolah di dunia mengalami karies. ${ }^{1}$ Karies merupakan penyakit gigi yang penyebabnya multifaktorial, yaitu mikroorganisme, host, substrat dan waktu. Keempat faktor ini saling berkaitan satu sama lain. ${ }^{2}$

Peningkatan prevalensi karies berhubungan signifikan dengan peningkatan frekuensi konsumsi makanan maupun minuman manis. ${ }^{3}$ Selain itu, didapati hubungan bermakna antara frekuensi menyikat gigi dengan kejadian dan keparahan karies. ${ }^{4,5}$ Kunjungan ke dokter gigi secaran rutin minimal 6 bulan sekali disarankan untuk tindakan pencegahan karies. ${ }^{6}$ Kunjungan rutin juga dapat mencegah suatu penyakit menjadi lebih parah. Pengetahuan yang kurang dan ketakutan untuk datang ke dokter gigi menyebabkan banyaknya orang yang datang ke dokter gigi untuk pengobatan dari pada pencegahan. ${ }^{7}$

Kesehatan gigi dan mulut termasuk salah satu unsur kesejahteraan yang harus dicapai. Tujuan diadakannya penelitian ini adalah untuk mengetahui hubungan antara konsumsi snack, menyikat gigi dan kunjungan ke dokter gigi terhadap kejadian karies. Dalam penelitian ini variabel tersebut diteliti menggunakan nilai rerata yang akan diperoleh dari hasil skor kuesioner.

Beberapa penunjang seperti fasilitas kesehatan yang memadai dan terjangkau, serta kemajuan teknologi dalam bidang ilmu komunikasi dapat memudahkan seseorang untuk mencapai tingkat kesehatan yang lebih baik. SMP Santo Yoseph merupakan sekolah yang terletak di kota Denpasar yang memiliki faktor-faktor penunjang diatas. Olehkarena itu peneliti ingin mengetahui dengan keadaan lingkungan yang memiliki faktor-faktor penunjang tersebut bagaimanakah tingkat karies pada siswa yang bersekolah di SMP Santo Yoseph.

\section{METODE}

Penelitian ini menggunaka rancangan studi analitik potong lintang. Penelitian ini dilakukan pada bulan Oktober 2016 di SMP Santo Yoseph Denpasar. Sampel diambil menggunakan metode purposive sampling. Dalam penelitian ini sebanyak 102 siswa kelas VII SMP Santo Yoseph Denpasar yang telah memenuhi kriteria inklusi menjadi sampel penelitian. Penelitian ini dilakukan dengan wawancara terstruktur dibantu dengan kuesioner. Pemeriksaan karies dilakukan oleh asisten penelitian yang telah diberi arahan dalam melakukan screening.

Data yang diperoleh kemudian diolah dengan analisis univariat dan bivariat menggunaka chi-square. Analisis univariat digunakan untuk menjelaskan karakteristik sampel dengan hasil proporsi dan persentase. Analisis bivariat digunakan untuk mengetahui hubungan antara variabel bebas (konsumsi makanan ringan atau minuman manis, menyikat gigi dan kunjungan ke dokter gigi) dan variabel terikat (karies).

Konsumsi makanan ringan atau minuman manis dibagi dalam 2 kategori yaitu perilaku baik (frekuensi konsumsi $<12 \mathrm{kali} / \mathrm{minggu}$ ) dan perilaku buruk (frekuensi konsumsi $\geq 12$ kali/ minggu) yang diperoleh dari rerata konsumsi per minggu sampel. Sistem skoring digunakan dalam pengkategorian perilaku menyikat gigi yang terdiri dari 8 pertanyaan, yang kemudian perilaku menyikat gigi dikelompokkan menjadi perilaku baik (skor $\geq 14$ ) dan perilaku buruk (skor $<14$ ). Sedangkan dalam kategori kunjungan ke dokter gigi dibagi menjadi perilaku baik (jika pernah mengunjungi doker gigi dalam setahun) dan perilaku kurang baik (jika dalam setahun terakhir tidak pernah mengunjungi dokter gigi).

\section{HASIL}

Penelitian ini menggunakan rancangan potong lintang yang melibatkan 102 orang subjek penelitian yang berasal dari SMP Santo Yoseph, karakteristik subjek penelitian dapat dilihat pada Tabel 1 .

Berdasarkan tabel 1, sampel terbanyak berusia 12 tahun $(87,3 \%)$ dan berjenis kelamin laki-laki (51,0\%). Sampel dengan pendidikan ayah terbanyak didapati pada kategori PT (perguruan tinggi) yaitu sebanyak 74 orang $(72,6 \%)$ dan pendidikan ibu terbanyak juga didapati pada kategori PT (perguruan tinggi) yaitu sebanyak 61 orang $(59,8 \%)$. Sedangkan tingkat pendapatan orang tua terbanyak didapati pada sampel dengan pendapatan orang tua $\geq 5.000 .000$ /bulan sebanyak 79 orang $(77,5 \%)$.

Berdasarkan tabel 2, dapat dilihat bahwa 52,0\% sampel memiliki status karies. Sebanyak 47 sampel (46,1\%) memiliki perilaku konsumsi makanan ringan atau minuman manis dengan frekuensi $<12 \mathrm{kali} /$ minggu, dengan frekuensi rata-rata $14,57 \mathrm{kali} / \mathrm{minggu} \pm \mathrm{SD} 8,842$. Sampel yang memiliki perilaku menyikat gigi baik sebanyak 69 orang (67,6\%). Tabel 2 juga memaparkan bahwa ada 66 sampel (64,7\%) yang memiliki kunjungan ke dokter gigi dengan status baik. 
Tabel 1 Distribusi sosiodemografi subjek penelitian

\begin{tabular}{lcc}
\hline Karakteristik & Frekuensi (n) & Persentase (\%) \\
\hline Usia & 89 & 87,3 \\
12 tahun & 13 & 12,7 \\
13 Tahun & & \\
Jenis Kelamin & 52 & 51,0 \\
$\quad$ Laki-laki & 50 & 49,0 \\
Perempuan & & \\
Pendidikan Ayah & 28 & 27,4 \\
$\quad \leq$ SMA & 74 & 72,6 \\
PT & & \\
Ibu & 41 & 40,2 \\
$\quad \leq$ SMA & 61 & 59,8 \\
PT & & \\
Pendapatan orang tua & & 22,5 \\
$<5.000 .000$ / bulan & 23 & 77,5 \\
$\geq 5.000 .000$ / bulan & 79 & \\
\hline
\end{tabular}

Tabel 2 Distribusi frekuensi status karies, konsumsi makanan ringan atau minuman manis, menyikat gigi, dan kunjungan ke dokter gigi sampel

\begin{tabular}{lcc}
\hline Karakteristik & Frekuensi (n) & Persentase (\%) \\
\hline Status karies & & \\
$\quad$ Karies & 53 & 52,0 \\
$\quad$ Tidak karies & 49 & 48,0 \\
$\begin{array}{l}\text { Konsumsi makanan ringan atau } \\
\text { minuman manis }\end{array}$ & & \\
$\quad<12$ kali /minggu & 47 & 46,1 \\
$\quad \geq 12$ kali /minggu & 55 & 53,9 \\
Menyikat gigi & & \\
$\quad$ Baik & 69 & 67,6 \\
$\quad$ Buruk & 33 & 32,4 \\
Kunjungan ke dokter gigi & & \\
$\quad$ Baik & 66 & 64,7 \\
$\quad$ Buruk & 36 & 35,3 \\
\hline
\end{tabular}

Tabel 3 menunjukkan sampel dengan status karies terbanyak didapati pada sampel yang berusia 12 tahun $(88,7 \%)$, dan didapati pada sampel laki - laki $(52,8 \%)$ dibandingkan dengan sampel perempuan yaitu 25 orang $(47,2 \%)$. Status karies terbanyak berasal dari ayah yang berpendidikan PT (perguruan tinggi), yaitu sebanyak 38 sampel $(71,7 \%)$ dan status karies terbanyak juga didapati pada sampel dengan ibu yang berpendidikan PT yaitu sebanyak 33 orang $(62,3 \%)$. Tabel diatas juga memaparkan bahwa status karies terbanyak didapati pada sampel dengan tingkat pendapatan orang tua $\geq 5.000 .000 /$ bulan yaitu sebanyak 40 orang $(75,5 \%)$.

Berdasarkan hasil uji analisis Chi Square antara konsumsi makanan ringan atau minuman manis dengan kejadian karies (tabel 4), didapatkan nilai $\mathrm{p}=0,305$. Dari hasil tersebut dapat ditarik kesimpulan bahwa terdapat hubungan yang tidak bermakna secara statistik antara konsumsi makanan ringan atau minuman manis dengan kejadian karies pada siswa kelas VII SMP Santo Yoseph Denpasar. Berdasarkan nilai OR yang didapat, siswa SMP Santo Yoseph yang memiliki perilaku konsumsi makanan ringan atau minuman manis $\geq 12 \mathrm{kali} /$ minggu 1,5 kali akan mengalami kejadian karies dibandingkan dengan siswa yang memiliki perilaku konsumsi makanan ringan atau minuman manis $<12 \mathrm{kali} /$ minggu.

Berdasarkan hasil uji analisis Chi Square antara perilaku menyikat gigi dengan kejadian karies didapatkan nilai $\mathrm{p}<0,001$. Dari hasil tersebut dapat disimpulkan bahwa terdapat hubungan yang bermakna secara statistik antara perilaku menyikat gigi dengan kejadian karies pada siswa kelas VII SMP Santo Yoseph Denpasar. Berdasarkan nilai OR yang didapat, siswa kelas VII SMP Santo Yoseph yang memiliki perilaku buruk dalam menyikat gigi 7,5 kali akan mengalami kejadian karies dibandingkan dengan siswa yang memiliki perilaku menyikat gigi yang baik. Berdasarkan hasil uji analisis Chi Square antara kunjungan ke dokter gigi dengan kejadian karies, didapatkan nilai $\mathrm{p}=0,903$. Dari hasil tersebut dapat ditarik kesimpulan terdapat hubungan yang tidak bermakna secara statistik antara kunjungan ke dokter gigi dengan kejadian karies pada siswa kelas VII SMP Santo Yoseph Denpasar. Berdasarkan nilai OR yang didapat, siswa kelas VII SMP Santo Yoseph yang memiliki kunjungan ke dokter gigi yang buruk memiliki risiko 1,5 kali lebih besar untuk mengalami kejadian karies dibandingkan dengan siswa yang memiliki kunjungan ke dokter gigi yang baik.

\section{PEMBAHASAN}

Menurut hasil penelitian yang diperoleh, prevalensi karies siswa kelas VII (12 - 13 tahun) SMP Santo Yoseph Denpasar sebesar 52,0\%. Penelitian yang dilakukan di Qatar mendapatkan prevalensi karies pada anak sekolah usia 12 - 13 tahun sebesar $83,4 \% .^{8}$ Selain itu pada penelitian lain menyebutkan prevalensi karies pada anak usia 12 tahun sebesar 53,8\%.9 Pada penelitian ini 
Tabel 3 Distribusi karies berdasarkan sosiodemografi sampel

\begin{tabular}{|c|c|c|}
\hline \multirow[b]{2}{*}{ Karakter Sosiodemografi } & \multicolumn{2}{|c|}{ Status Penyakit } \\
\hline & Karies & Tidak Karies \\
\hline & n (\%) & n (\%) \\
\hline \multicolumn{3}{|l|}{ Usia } \\
\hline 12 tahun & $47(88,7 \%)$ & $42(85,7 \%)$ \\
\hline 13 tahun & $6(11,3 \%)$ & $7(14,3 \%)$ \\
\hline \multicolumn{3}{|l|}{ Jenis Kelamin } \\
\hline Laki-laki & $28(52,8 \%)$ & $24(49,0 \%)$ \\
\hline Perempuan & $25(47,2 \%)$ & $25(51,0 \%)$ \\
\hline \multicolumn{3}{|l|}{ Pendidikan Ayah } \\
\hline$\leq \mathrm{SMA}$ & $15(28,3 \%)$ & $13(26,5 \%)$ \\
\hline PT & $38(71,7 \%)$ & $36(73,5 \%)$ \\
\hline \multicolumn{3}{|l|}{ Ibu } \\
\hline$\leq \mathrm{SMA}$ & $20(37,7 \%)$ & $21(42,9 \%)$ \\
\hline PT & $33(62,3 \%)$ & $28(57,1 \%)$ \\
\hline \multicolumn{3}{|l|}{ Pendapatan orang tua } \\
\hline$<5,000,000 /$ bulan & $13(24,5 \%)$ & $10(20,4 \%)$ \\
\hline$\geq 5,000,000$ /bulan & $40(75,5 \%)$ & $39(79,6 \%)$ \\
\hline
\end{tabular}

Tabel 4 Hubungan konsumsi makanan ringan atau minuman manis, menyikat gigi, dan kunjungan ke dokter gigi terhadap karies

\begin{tabular}{|c|c|c|c|c|}
\hline & \multicolumn{2}{|c|}{ Status Penyakit } & \multirow[b]{3}{*}{ OR (IK 95\%) } & \multirow[b]{3}{*}{$p$} \\
\hline & Karies & Tidak Karies & & \\
\hline & n (\%) & n (\%) & & \\
\hline \multicolumn{5}{|l|}{$\begin{array}{l}\text { Konsumsi makanan } \\
\text { ringan atau } \\
\text { minuman manis }\end{array}$} \\
\hline$\geq 12 \mathrm{kali} / \mathrm{minggu}$ & $26(49,1 \%)$ & $29(59,2 \%)$ & \multirow{2}{*}{$1,506(0,688-3,298)$} & \multirow{2}{*}{0,305} \\
\hline$<12$ kali/minggu & $27(50,9 \%)$ & $20(40,8 \%)$ & & \\
\hline \multicolumn{5}{|l|}{ Menyikat gigi } \\
\hline Buruk & $27(50,9 \%)$ & $6(12,2 \%)$ & \multirow{2}{*}{$7,442(2,711-20,429)$} & \multirow{2}{*}{$<0,001$} \\
\hline Baik & $26(49,1 \%)$ & $43(87,8 \%)$ & & \\
\hline \multicolumn{5}{|l|}{$\begin{array}{l}\text { Kunjungan ke dokter } \\
\text { gigi }\end{array}$} \\
\hline Buruk & $19(35,8 \%)$ & $17(34,7 \%)$ & $1,502(0,466-2,372)$ & 0,903 \\
\hline Baik & $34(64,2 \%)$ & $32(65,3 \%)$ & & \\
\hline
\end{tabular}

ditemukan bahwa proporsi karies pada sampel berusia 12 tahun dengan sampel berusia 13 tahun yang hampir sama. Namun, menurut Fejerskov prevalensi karies meningkat seiring dengan bertambahnya usia, hal ini disebabkan karena gigi yang sudah erupsi akan lebih lama terpapar dengan faktor risiko penyebab karies. ${ }^{10}$
Data yang didapat juga memaparkan bahwa status karies lebih banyak terjadi pada sampel laki - laki yaitu 28 orang (52,8\%) dibandingkan dengan sampel perempuan yaitu 25 orang $(47,2 \%)$. Hal ini sejalan dengan penelitian yang dilakukan oleh Mangkey dkk, yaitu lebih tinggi tingkat karies pada anak laki-laki dibandingkan dengan anak permpuan. ${ }^{11} \mathrm{Hal}$ ini mungkin disebabkan adanya kecenderungan anak perempuan yang lebih memperhatikan kebersihan gigi dan mulut dibandingkan dengan anak laki - laki.

Hasil penelitian ini bertolak belakang dengan penelitian yang dilakukan di Jepang, dimana karies pada anak perempuan lebih tinggi dibandingkan dengan anak laki - laki. Dalam penelitian tersebut, dijelaskan bahwa waktu erupsi gigi anak perempuan yang lebih cepat dibandingkan dengan anak laki-laki serta kebiasaan anak perempuan yang lebih menyukai makanan manis dan berpenampilan menarik dibandingan dengan anak laki - laki merupakan faktor peningkat karies pada anak perempuan. ${ }^{12}$ Pada penelitian ini peneliti menemukan bahwa perilaku konsumsi makanan ringan atau minuman manis antara sampel laki - laki dan perempuan di SMP Santo Yoseph hampir sama.

Dilihat dari pendidikan formal orang tua, pada penelitian ini didapati bahwa status karies terbanyak didapati pada sampel dengan dengan ayah berpendidikan PT (perguruan tinggi) yaitu sebanyak 38 sampel (71,7\%). Status karies terbanyak juga didapati pada sampel dengan ibu berpendidikan PT (perguruan tinggi) sebanyak 33 orang (62,3\%). Hasil penelitian ini juga sama dengan trend pada penelitian yang dilakukan di beberapa negara berkembang, dimana didapatkan hasil bahwa prevalensi karies yang tinggi banyak ditemukan pada anak yang memiliki orang tua dengan pendidikan dan penghasilan tinggi. ${ }^{13,14}$ Menurut sebuah penelitian yang dilakukan di Padang, pendidikan turut mempengaruhi status kesehatan dimana seseorang yang memiliki pendidikan tinggi akan memiliki pengetahuan yang lebih baik untuk berperilaku hidup sehat. ${ }^{14}$

Status karies tertinggi didapati pada sampel dengan pendapatan orang tua $\geq 5.000 .000 /$ bulan yaitu sebanyak 40 sampel $(75,5 \%)$ dibandingkan dengan sampel yang pendapatan orang tuanya $<5.000 .000 /$ bulan. Anak dengan pendapatan orang tua tinggi cenderung mengonsumsi makanan kariogenik lebih banyak sehingga menyebabkan karies, namun seseorang dengan tingkat pendapatan yang tinggi juga ada kecenderungan untuk mendapatkan perawatan gigi yang lebih baik dibanding dengan tingkat pendapatan yang rendah. ${ }^{15}$ 
Menurut penelitian yang dilakukan oleh Moynihan dkk pada tahun 2004, tingginya angka kejadian karies berhubungan dengan frekuensi konsumsi makanan yang manis diantara jam makan. Kelompok anak yang mengkonsumsi makanan manis 4 - 5 kali dalam sehari memiliki kecenderungan peningkatkan risiko karies sebesar 6 kali. ${ }^{16}$ Dalam penelitian ini, sebagian besar sampel (92\%) mengkonsumsi makanan ringan atau minuman manis $\leq 4$ kali dalam sehari, maka peneliti menggunakan nilai median (12 kali/minggu) dalam pengkategorian baik dan buruk.

Terdapat hubungan antara perilaku konsumsi makanan ringan atau minuman manis dengan kejadian karies yang tidak bermakna secara statistik, dengan nilai $\mathrm{p}=0,305$. Berdasarkan nilai OR yang didapat, sampel yang mempunyai perilaku konsumsi makanan ringan atau minuman manis $\geq 12 \mathrm{kali} /$ minggu 1,506 kali akan mengalami kejadian karies dibandingkan sampel yang mempunyai perilaku konsumsi $<12 \mathrm{kali} /$ minggu. Penelitian lain menunjukkan hasil yang bermakna secara statistik antara hubungan konsumsi makanan manis dengan kejadian karies. ${ }^{17,18}$ Menurut penelitian yang dilakukan oleh Moynihan dkk pada tahun 2004, tingginya angka kejadian karies berhubungan dengan frekuensi konsumsi makanan yang manis diantara jam makan.

Kebiasaan menyikat gigi yang baik merupakan cara paling efektif untuk mencegah karies gigi. ${ }^{19}$ Hasil penelitian menunjukkan terdapat hubungan antara perilaku menyikat gigi dengan kejadian karies yang bermakna secara statistik pada siswa SMP Santo Yoseph Denpasar, dengan nilai $p=0,000$. Berdasarkan nilai $O R$ yang didapat, sampel yang mempunyai perilaku menyikat gigi buruk 7,442 kali akan mengalami kejadian karies dibandingkan sampel yang mempunyai perilaku menyikat gigi baik. Hasil penelitian ini sejalan dengan penelitian yang dilakukan di Albania dan Kenya yang menyatakan bahwa terdapat hubungan secara statistik antara kebiasaan menyikat gigi dengan kejadian karies. ${ }^{20,21}$

Kunjungan ke dokter gigi dimaksudkan untuk memantau kesehatan gigi dan mulut anak dari tahun ke tahun, selain itu juga menurunkan risiko kehilangan gigi karena karies. ${ }^{22}$ Terdapat hubungan antara kunjungan ke dokter gigi dalam satu tahun terakhir dengan kejadian karies yang tidak bermakna statistik, dengan nilai $\mathrm{p}=0,903$. Berdasarkan nilai OR yang didapat, sampel yang mempunyai perilaku kunjungan ke dokter gigi buruk 1,502 kali akan mengalami kejadian karies dibandingkan sampel yang mempunyai kunjungan ke dokter gigi baik. Penelitian ini sejalan dengan yang dilakukan di Albania bahwa tidak ada hubungan secara statistik antara kunjungan ke dokter gigi dengan karies, dengan nilai $\mathrm{p}=0,059$ dan nilai $\mathrm{OR}=2,700 .{ }^{20}$ Penelitian ini menunjukkan sampel dengan kategori baik dalam kunjungan ke dokter gigi dalam setahun sebesar $64,7 \%$. Hal ini bertolak belakang dengan beberapa penelitian, dimana hasil penelitian menyatakan dalam setahun sebagian besar subjek penelitian tidak pernah memeriksakan gigi ke dokter gigi dan hanya memeriksakan gigi jika telah mengeluhkan sakit. $^{21-26}$

Pada penelitian ini didapati hasil sampel yang pernah berkunjung ke dokter gigi dalam satu tahun terakhir memiliki status karies yang lebih banyak dibandingkan dengan status tidak karies. Namun, alasan kunjungan ke dokter gigi untuk kontrol rutin menunjukkan angka sampel yang lebih sedikit mengalami karies, sedangkan alasan lain seperti cabut gigi, sakit gigi dan tambal gigi menunjukkan angka sampel yang lebih banyak mengalami karies meskipun alasan kontrol rutin merupakan yang terbanyak ditulis sampel. Penelitian yang dilakukan di Kenya pada anak usia 12 tahun juga mendapati hasil yang sama, dimana anak yang pernah berkunjung ke dokter gigi dalam satu tahun terakhir memiliki prevalensi karies yang lebih besar. ${ }^{21}$

Hasil penelitian ini menunjukkan bahwa perilaku menyikat gigi yang paling berpengaruh terhadap kejadian karies. Namun masih terdapat beberapa keterbatasan dalam penelitian ini antara lain peneliti tidak memeriksa atau mengobservasi metode menyikat gigi yang digunakan oleh sampel, cara pemeriksaan karies yang dilakukan juga hanya mengandalkan visual dan taktil, sehingga karies yang tidak terlihat secara visual seperti karies pada bagian proksimal gigi tidak dapat tercatat. Pada penelitian ini peneliti juga tidak membedakan keparahan karies dan tidak mendata tanggal berkunjung ke dokter gigi dalam satu tahun terakhir sehingga perlu dilakukan penelitian lebih lanjut untuk mengetahui hubungan antara faktor tersebut diatas.

\section{SIMPULAN}

Angka kejadian karies pada siswa kelas VII SMP Santo Yoseph sebesar 52,0\%. Terdapat hubungan antara perilaku menyikat gigi terhadap kejadian karies pada siswa kelas VII SMP Santo Yoseph yang bermakna secara statistik.

\section{DAFTAR PUSTAKA}

1. Cheng YC, Huang $\mathrm{HK}$, Wu CH, et al. Correlation between dental caries and diet, oral hygiene habits, and other indicators among elementary school children in Xiulin township, Hualien county, Taiwan. Tzu Chi Medical Journal. 2014;26:175-81. 
2. Achmad MH. Buku Saku Karies dan Perawatan Pulpa pada Anak. 1st ed. Jakarta: Sagung Seto; 2015.55-7

3. Lakhanpal M, Chopra A, Rao NC, et al. Dietary pattern, tooth brushing habits and caries experience of school children in Panchkula district, India. Ann Public Health Res. 2014;1(1):10-18.

4. Chankanka O, Marshall TA, Levy SM, et al. Mixed dentition cavitated caries incidence and dietary intake frequencies. Pediatr Dent. 2011;33(3):233-40.

5. Leake J, Jozzy S, Uswak G. Severe dental caries, impacts and determinants among children 2-6 years of age in inuvik region, northwest territories, Canada. JCDA. 2008;74(6):519-522.

6. Hanapi AN. Angka kejadian karies dan gingivitis pada anak sekolah dasar usia 8-12 tahun di kabupaten Maros tahun 2014. [skripsi]. Makassar: Fakultas Kedokteran Gigi Hasanuddin; 2014.

7. Kamran A, Bakhteyar K, Heydari H, et al. Survey of oral hygiene behaviours, knowledge and attitude among school children: a cross-sectional study from Iran. International Journal Health Sciences. 2014;2(2):83-95.

8. Al-Darwish M, Ansari WE, Bener A. Prevalence of dental caries among 12-14 year old children in Qatar. Saudi Dental Journal. 2014;26:115-25.

9. Shah A F, Batra M, Kabasi S, et al. Dental caries experience among 6-12 year old school children of Budgam district, Jammu and Kashmir state India. Asian Pac. J. Health Sci. 2015;2(1):55-9.

10. Fejerskov O, Nyvad B, Kidd, E. Dental Caries: The Disease and its Clinial Managemets. $2^{\text {nd }}$ ed. Fejerskov O Kidd, E, editor. United Kingdom: Blackwell Munksgaard. 2008.

11. Mangkey E, Posangi J, Leman MA. Gambaran status karies pada siswa SMP negeri I Tomohon. Jurnal e-GiGi. 2015;3(1):182-88.

12. Fujita H, Asakura K, Ogura M. Age and sex-related dental caries prevalence in Japanese from the Jomon period. Journal Oral Biosciences. 2007;60(3):198-204.

13. Popoola BO, Denloye OO, Iyun OI. Influence of parental socioeconomic status on caries prevalence among children seen at the university college hospital, Ibadan. Annals Ibadan Postgraduate Medicine. 2013;11(2):81-6.

14. Susi, Bachtiar H, Azmi U. Hubungan status sosial ekonomi orang tua dengan karies pada gigi sulung anak umur 4 dan 5 tahun. Majalah Kedokteran Andalas. 2012; 36(1):96-105

15. Ngantung RA, Pangemanan DHC, Gunawan PN. Pengaruh tingkat sosial ekonomi orangtua terhadap karies anak di TK Hang Tuah Bitung. Jurnal e-GiGi. 2015;3(2): 542-8.
16. Moynihan P, Petersen PE. Diet, nutrition and the prevention of dental diseases. Public Health Nutrition. 2004;(1A)7:201-26.

17. Sumini, Amikasari B, Nurhayati D. Hubungan konsumsi makanan manis dengan kejadian karies gigi pada anak prasekolah di TK B RA Muslimat PSM Tegalrejo desa Semen kecamatan Nguntoronadi kabupaten Magetan. Jurnal Delima Harapan. 2014;3(2):20-7.

18. Talibo RS, Mulyadi, Bataha Y. Hubungan frekuensi konsumsi makanan kariogenik dan kebiasaan menggosok gigi dengan kejadian karies gigi pada siswa kelas III SDN 1 \& 2 Sonuo. e-Journal Keperawatan. 2016;4(1):5-10.

19. Rahim R. Hubungan kebiasaan menggosok gigi malam hari dan kejadian karies gigi ada anak sekolah dasar negeri Karang Tengah 07 Tangerang. Forum Ilmiah. 2015;12(1):74-79.

20. Hysi D, Droboniku E, Toti C, et al. Dental Caries experience and oral health behaviour among 12 -year-olds in the city of Tirana, Albania.J Oral Healt Oral Epidemiol. 2010;5(1):1-12

21. Gathecha G K. Dental caries and its relationship to oral health knowledge and practice among 12 year old children in Nairobi west district Kenya. Tesis. 2012;47

22. Mustika A C. Gambaran sikap kunjungan ke dokter gigi dan status karies siswa kelas VII (usia 12-13 tahun ) di SMP Negeri 3 kecamatan Cepu kabupaten Blora. 2016;6.

23. Sutjipto C, Wowor VNS, Kaunang WPJ. Gambaran tindakan pemeliharaan kesehatan gigi dan mulut anak usia 10 - 12 tahun di SD Kristen Eben Haezar 02 Manado. Jurnal e-Biomedik (eBM). 2013;1(1):697-706.

24. Jürgensen N, Petersen PE. Oral health and the impact of socio-behavioral factors in a cross sectional survey of 12-year old school children in Laos. BMC Oral Health. 2009 Nov; 9(29).

25. Adekoya-Sofowora CA, Nasir WO, Oginni AO, Taiwo M. Dental caries in 12-year-old suburban nigerian school children. African Health Sciences. 2006;6(3): 147-151.

26. Lely Suratri, M., N, I., Setiawaty, V. Correlation between dental health maintenance behavior with Dental Caries Status (DMF-T). 2018. Bali Medical Journal 7(1): 56-60. DOI:10.15562/bmj.v7i1.836

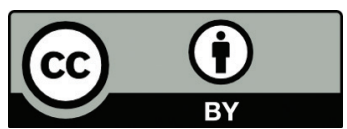

This work is licensed under a Creative Commons Attribution 